\title{
Eräistä suomen syntaktisista siirtymistä
}

Yleisesti tunnettuja ovat muutamat sellaiset tapaukset, joissa jonkin ilmaustyypin syntaktisessa rakenteessa on tapahtunut siirtyminen, ts. jonkin lauseenjäsenen asema muiden lauseenjäsenten joukossa on muuttunut. Tällä tavoin on syntynyt uudenlaisia rakenteita, jotka usein ovat merkinneet kielen ilmaisumahdollisuuksien lisääntymistä. Tällaisiin syntaktisiin siirtymiin perustuvat rakenteet ovat monesti niitä, joiden analysoiminen puhtaasti synkroniselta kannalta tuottaa vaikeuksia. Jo E. N. SEтÄL Ä on lauseopissaan kiinnittänyt huomiota siihen seikkaan, etteivät infinitiivit alkuaan ole olleet subjekteja eivätkä objekteja ja ettei niillä substantiivinluonteensa vuoksi myöskään ole itsellään ollut objektia: "Semmoisessa lausetyypissä kuin paras on ottaa kirves mukaan on kirves alkuperin subjektina ja ottaa ainoastaan 'suhteen' määrääjänä. Semmoisten nykyjään yksipersoonisten verbien ohessa kuin pitää, tulee, tarvitsee, sopii j.n.e. on myös alku.jaan se olio, joka on tarpeen j.n.e., ollut ilmaistuna vastaavan sanan perusmuodolla, joka on ollut kieliopillisena subjektina puheenalaista laatua olevalle verbille, se olio taas, jolle jokin on ollut tarpeen, jolle jokin tehtävä tulee, on ilmaistu vastaavan sanan (datiivisella) genetiivillä. Sijs: Koira pitä̈̈ tappaa on alkujaan ollut eriteltävä näin: koira subj., pitää pred., tappaa = tapettavaksi, tarkoituksen inf.,_ _ - Minun pitää koira tappaa = koira pitää minun (s.o. minulle, datiiviadverbiaali) tapettavaksi. _ _ _ Semmoisessa lausetyypissä taas kuin minä tahdon sen tehdä on sen ollut tahdon verbin eikä infinitiivin objekti (_- -). Sitä paremmin ymmärrämme rakenteen: käske tuoda hevonen tänne, joka siis on alkuperin eritelty: käske hevonen tänne tuotavaksi." (SKL $\S 30,6$.)1 Nämä SEтÄLän selitykset on vleisesti hyväksytty. 2 Äsket-

1 Tässä kirjoituksessa käytettyjä lyhennyksiä: Agricola = Mikael Agricolan teokset, faksimilepainos, Porvoo 1931; numerot tarkoittavat tämän painoksen: 
täin olen julkisuudessa kiinnittänyt huomiota exääseen toiseen ilmaustyyppiin, jossa on tapahtunut samantapainen siirtyminen: määräsin kirjelmään tehtäväksi tarpeelliset muutokset yms. Tässä tyypissä on tarpeelliset muutokset alkuaan ollut finiittimuodon objekti, mutta nykykielessä tyyppi useasti jäsentyy toisin (ks. UAJJ XXVIII s. 201-).

Nykysuomessa on edellä mainittujen lisäksi monia muitakin sellaisia ilmaustyyppejä, jotka perustuvat samantapaisiin siirtymiin. Seuraavassa tarkastelen sellaisia tapauksia, joissa passiivisen fỉnïtimuodon subjekti on siirtynyt saman muodon objektiksi tai joissa finiittimuodon subjekti tai objekti on siirtynyt joko infinitiivin tai passiivisen partisiipin objektiksi. Täydellisyyden vuoksi mainitsen nekin tapaukset, joihin jo ennen on huomiota kiinnitetty; toisaalta ne muiden samantapaisten yhteyteen asetettuina saavat uutta valaistusta, toisaalta: ne myös auttavat ymmärtämään muita esitettäxiä siirtymï.

osia ja sivuja. - HAKULINEN SKRK = LAUR HAKULINEN Suomen kielen rakenne ja kehitys I-II, Helsinki 1941, 1946. - IkolA TMK=Osmo IKoLA Tempusten ja modusten käyttö ensimmäisessä suomalaisessa raamatussa verrattuna vanhempaan ja nykyiseen kieleen I-II, Turun yliopiston julkaisuja B XXXII, XXXIV, Turku 1949, 1950. - KANNIsTo LHLEH = ARTTURI KANNIsTo Lauseopillisia havaintoja läntisen Etelä-Hämeen kielimurteesta, Suomi III 20, Helsinki 1902. - KKN III = Karjalan kielen näytteitä III, julk. EıNo JESKINEN, Helsinki 1936. - LATVALA LMPS = SALU LATVALA Lauseopillisia muistiinpanoja Pohjois-Savon murteesta, Suomi III 17, Helsinki 1899. - Mannerheim $=\mathrm{G}$. ManNerherm Muistelmat $\mathrm{I}-\mathrm{II}$, suomentanut Ladri HaKulinen, Helsinki 1951, 1952. -- NS = Nykysuomen sanakirja. - OJANsuU MAK= Herkm OJansu Mikael Agricolan kielestä, Suomi IV 7, Helsinki 1909. Pentrilï SK $=$ AARni Pentrill Suomen kielioppi, Porvoo 1957. - SETÄLÄ LTKS $=$ E. N. SETÄL lestä, Suomi II 16, Helsinki 1883. - SFı̈̆L̈̈ SKL = E. N. SETäL Ä Suomen kielen lauseoppi oppikouluja varten, 12. p., Helsinki 1942. - Sirelius LTJK = U. T. SIRELIUs Lanseopillinen, tutkimus Jääsken ja Kirvun kielimurteesta, Suomi III 10, Helsinki 1894. SKM I = Suomen kielen muistomerkkejä I, Helsinki 1893. - SS = Sanakirjasäätiön kokoelmat; pääasiallisesti olen käyttänyt Turun yliopiston suomen kielen laitoksessa olevia mikrofilmijäljennöksiä. - UA = Uusi Aura. - UAJb = Ural-Altaische Jahrbücher. - US = Uusi Suomi. Suomen pitäjien nimiä lyhentäessäni olen noudattanut Vir. 1950 ss. $427-428$ julkaistua luetteloa.

2 Toisin kuitenkin W. GRÜNTHAI Itämerensuomalaisten kielten yksikön nominatiivi objektin edustajana aktiivin yhteydessä, Helsinki 1941, s. 288-. 


\section{Passivisen finiittimuodon subjeliti siirtynyt saman muodon objektiksi}

\section{Tyyppi työ tehdään.}

Yleisen käsityksen mukaan on suomen passiivi aikaisemmin ollut persoonallinen: se lauseenjäsen, jonka nykyään käsitämme passiivimuodon objektiksi, on ollut subjekti (ks. esim. SErüL SKL § 30,5; OJAnsuU MAK ss. 103-104; HAKULINFn SKRK I § 59, II § 34). Tästä johtuvaksi on selitetty $\mathrm{mm}$. passiivin kokonaisobjektin nominatiivimuot@isuus. Äskettäin manan majoille siirtynyt tutkija Jurius vON FARKas esitti kuitenkin parisen vuotta sitten sellaisen mielipiteen, ettei suomen passiivi olekaan koskaan ollut persoonallinen, vaan että nykykieli edustaa alkuperäistä kantaa (UAJb XXVIII s. 261 ; ks. myös W. Krause ibid. s. $175-$ ).

Tähänastisen käsityksen puolesta puhuvat kuitenkin niin monet seikat, etteivät VON FARKAsin esittämät näkökohdat mielestäni pysty sitä horjuttamaan. Hän otaksuu, että suomalaiset ja virolaiset hengellisten tekstien kääntäjät koettaessaan mahdollisimman uskollisesti noudattaa latinalaista alkutekstiä loivat passiivin persoonamuodot latinan esikuvan mukaan. Ainakaan suomen kirjakielen historiassa ei latinan vaikutus ole ollut niin voimakas, että voitaisiin ajatellakaan passiivin persoonamuotojen selittyvän tällä tavoin. Virossa taas persoonapäätteelliset passiivimuodot eivät rajoitu vanhaan kirjakieleen, vaan niitä _ vieläpä kaikkien persoonien muotoja on todettu myös eteläviron kansanmurteista (ks. F. J. WIEDEMANN Versuch über den Werroehstnischen Dialekt, Pietari 1864, ss. 4142, ja Grammatik dex ehstnischen Sprache, Pietari 1875, s. 475; N. IкоLA Eteläviron verbien persoonapäätteistä, Suomi V 13, s. 65; J. Mägrstr: Vir. 1932 s. 416). Erityisesti on syytä panna merkille, että persoonapäätteelliset passiivimuodot ovat WIEDEMANNin mukaan etelävirossa yleisimmin käytännössä mon. 1. ja 3. persoonassa, siis juuri samoissa persoonissa, joihin vanhan kirjasuomen persoonapäätteelliset passiivimuodot melkein kokonaan rajoitturat.

Aikaisemman säännöllisen persoonallisen passiivin pohjalta selittyvät parhaiten myös seuraavanlaiset Westhin koodeksissa esiintyvät sekamuodostukset: tämä rumilinen colema - - cutzutat- ychdexi vnexi SKM I 81:23- / oli hän wighatoin ia pandit Paradissin elämän 235:3- | sillä tesse me rkit et me 133:2-- | 
E $t \approx i$ t t rumin terue ÿttce 131:10. Tällaiset esimerkit osoittavat, että passiivimuotojen persoonapäätteiden merkitystehtävä oli jo hämärtynyt. Jos näitä persoonapäätteellisiä muotoja pidettäisiin kirjoittajien keinotekoisesti luomina muodostuksina, olisi tällaista t-päätteen käyttöä vaikea selittää.

Myöntäviä persoonapäätteellisiä passiivimuotoja esiintyy vanhassa kirjasuomessa, kuten sanottu, (yks. 3. persoonaa lukuunottamatta) yleensä vain mon. 1. ja 3. persoonassa, ja nüissäkin ne ovat melko harvinaisia. ${ }^{3}$ Sen sijaan vastaavat kieltomuodot, joissa persoonapääte ei ole liittynyt päävèrbiin, vaan kieltoverbiin, ovat aivan yleisiä, vieläpä.kaikissa persoonissa. Esimm. Agricola: etten mine Iuttaille ylenannetaisi. II 299 / Elket domitko, nin ette te domita. II 182 / Westh: ia edt taita sine cadhotetta SKM I 150:20 / Raamattu 1642: en minä ikänäns cukisteta, Ps. 10:6 / ettet sinü kirotais, 5. Moos. 7:26/ ettes wietelläis hänen silmäins ki,losta. Sananl. 6:25 / ettet te lyödäis teidän wiholisildan. 5. Moos. 1:42. Yhtä yleistä on nykyistä persoonatonta passiivia vastaavan myöntävän muodon (oikeastaan yks. 3. persoonan) käyttö persoonallisena. Fsimm. Agricola: sine heiteten tornihin, II 32 / Nimitetän he tessa Kyliärmexi, IT 27 / Raam. 1642: minä hucutetron 1. Moos. 34:30 / Sillä sinun tähtes surmatan me jocapäiwä, Ps. 44:23/Etten me sillen lapset olis, jotca horjuisim ja caickinaisilda opetuxen tuulilda wietelläisin, Ef. 4:14 / ja sinä warjellan minun tykönäni. 1. Sam. 22:23. Erityisen valaisevia ovat seuraavat $1642: \mathrm{n}$ ramatun esimerkit, joissa yks. 2. persoona on passiivimuodonkin yhteydessä jlmaistu pelkällä $s$-suffiksilla $(<\sin \ddot{a}):$ Coscas ahdistetan, 5. Moos. t:30 / syö wijnamarjoja himos jälken, ettäs rawitan: 5. Moos. $23: 24$ / Ia syö sinun carjas hedelmän ja sinun maas hedelmän, sijhenasti ettäs hucutetan. 5. Moos. 28:51 / jolletcas tänä yönä henges päästä, nijns huomeneltain tapetan. 1. Sam. 19:11 / Ettäs warjellaisin pahasta waimosta, Sananl. $6: 24$. (Vanhan kirjasuomen passiivista lähemmin ks. Ikola TMK 1 s. 177-.)

: Vielä nyöhään, jopa nykypäivinäkin, saattaa tavata seuraavantyyppisiä passiivin imperatiivin mon. 3. persoonan muotoja: - - wiat ja ritokset tutkittakoot ja rangastakoot kaupungin Pormestarilta ja Raadilta. Turun Wiikkosanomat 1822, n:o 28, s. 111. Tällaisten esiintyminen näin myöhään perustuu aktiivin vastaavien muotojen analogiaan. Tämä tosiasia osoittaa, että passiivimuodon ns. objekti nykyisenkin kielitajun mukaan eräissä tapauksissa voitaisiin jokseenkin ylitä hyvin tulkita subjektiksi. 
Vaikkakaan suomen kansankielestä ei tunneta varsinaisia persoonapäätteellisiä passiivimuotoja, on siinäkin persoonalliseen passiiviin viittaavaa käyttöä, esim. Mul Se ei käytetä meijän paikkeilla SETÄLÄ LTKS \$ 197 / Kyl Ei se sanotak kasvava 4 Kannisto LHLEH s. 187 / Loi me sit vaan pirettiin hyvänä [s.o. meitä pidettiin] SS Ilma Hakulinen 1937 / Inkerin savakkomurre ei ne tuatu. Vir. 1953 s. 401 . Samantapaista on eräissä vanhoissa sananlaskuissa:

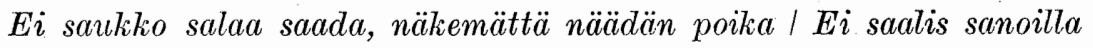
saada (ks. HAKULINEN SKRK II s. 238).

Agentin puuttuminen, johon voN Farkas myös vetoaa, on tietysti jotenkin yhteydessä sen suomen passiivin erikoisuuden kanssa, että se ilmoittaa tekijäksi epämääräisen persoon an (esim. ovi avattiin ei merkitse samaa kuin ovi aukesi). Nämä seikat selittyvät luontevasti, jos passiivimme on syntynyt kausatiivijohdannaisista, kuten on otaksuttu (ks. HaKulinen SKRK I § 59).

Edellä esittämäni seikat oikeuttavat mielestäni yhä olettamaan, että suomen passiivi voidaan palauttaa persoonalliseen, subjektilliseen passiiviin. Onko passiivissa ollut täydellinen persoonataivutus, kuten OJANsuU oletti, ja mitä on ollut tämän kehitysvaiheen takana, .jääköön tässä yhteydessä pohtimatta. Tärkeintä on tämänkertaisen aiheeni kannalta se, että alkuperäisen subjektin siirryttyä lauseessa uuteen funktioon on finiittimuoto jäänyt subjektittomaksi ja persoonattomaksi. Tässä suhteessa tämä siirtyminen liittyy niihin, joita käsitellään lähinnä setraavissa luvuissa (II ja III).

II. Finiittimuodon subjekti siirtynyt passiivisen partisiipin objektiksi 5

2. Tyyppi työ on tehty.

Vanhassa kirjasuomessa on aivan yleinen sellainen ilmaustyyppi, jossa nomini (tyyppiesimerkissämme työ) on subjekti, apuverbi

4. Murre-esimerkkien tarkekirjoitusta on tässä kirjoituksessa yksinkertaistettu, mikä - paitsi että se helpottaa painatusta - tekee esimerkit syntaktisia seikkoja ajatellen havainnollisemmiksi. Lähisukukielten esimerkeistä on vain diftongien kaaret jätetty pois.

5 Eräissä tapauksissa objekti yleisesti käsitetään kuuluvaksi apuverbin ja passiivin partisiipin muodostamaan liittomnotoon eikä pelkästään partisiippiin. Yksinkertaisuuden vuoksi poikkean tästä tavasta, koska otsakkeen edellyttämä jäsennystapakin mielestäni on mahdollinen. 
(on) predikaatti ja passiivin partisiippi (tehty) predikatiivi, esim. Agricola: ette pyhet miehet ia waimot meiden edhellem nin tehnyet ouat, Ia eiuet senuoxi ole laitetut. III 40 / Westh: ettäs nyt kijnni otettu olet ja pandu sijtteisin SKM I 99:15- / ennen qui me ylesotetudt olemma christust vastan 93:13- I Sorolainen: on sekä se manaus että Evangelium ia rwcous iotca wanhast ovat luetut ennen cuin rwmis vlgoswietin, täsä Käsikirias pannut luetta, Käsik. 6 / Egyptis eij ole yxikän joutilas kärsitty. Post. I 728 / ne iotca ovat 4. uscotut heidän Herraldans ylöscandaman heidän Alimaisildans ulgostegot: Post. II 269 / Raam. 1642: Cosca nämät wijsi Cuningast olit tuodut hänen eteens, Joos. 10:24 / nijncuin carhu, jolda pojat owat otetut kedolla pois, 2. Sam. 17:8 i ja en minä ole cudzuttu colmenakymmenenä päiwän̈̈ Cuningan tygö. Ester 4:11 / sillä jos Tyros ja Sidonis olis sencaltaiset woimalliset työt tehdyt, cuin täs $\ddot{a}$ owat tehdyt, Luuk. 10:13. Tällaiset vanhan kirjakielen ilmaukset vastaavat merkitystehtävältään täydellisesti nykyisiä verbin liittomuotoja; nämä ilmaisevat myös itse tapahtumaa eivätkä ainoastaan sen tuloksena olevaa tilaa kuten vastaavat ilmaukset nykyään (lähemmin ks. Ikola TMK II s. 88-; vrt. HakUlinen SKRK II s. 254-).

Samanlaista käyttöä tapaa nykyisistä kansanmurteistakin, esim. Kus ko neekki ova annetu märäntty / eluka olit tapetus siihem paikka | ne olis sillon kaik kyöräty oilkken kruunum puolest pakko, nii et Isoskaris olik kaikk asuno jätetyp pahure halttu Jouko VAHE: Kustavin murteen äännehistoria (laudaturtutkielma 1952, Turun yliopisto) ss. 38 ja $67 /$ Rym et ne [talot] oli oikke erotetu, etei ne ollu yhres O. Ikola 1952 / Tamp Mutta minkäslainer rouva te oletten kun te noin oletten tuatu putkaan seittemältä? VIrTaranta Aamulehti 8. 1. 52 / Keu Minä olisin aikoja tapettu jo SEräL $\S 197$ / Kuop En minä tänne oo ijankaekkiseks kiusaks pantu Suomen kansan murrekirja, Itämurteet, Porvoo 1945, s. 46. Samantapaista on lähisukukielissäkin, esim. karj. olemma tüönnettü ečč mäh - - KKN III 183:26 / lyyd. olìt sina lükìttùd tälлe peudŏлӗ vuorikš̆ı nokittavaksi' SUST 69 s. $77: 3$ - / hebod on d'o val'l'astetud 'Hevoset ovat jo valjastetut' 256:1- / vepsä sitp $\overline{\ddot{a}}$ paratud oma sihe raudad 'sieltäpäin viritetyt ovat siihen raudat' SUST 86 s. 62 । munad jo muidud 'munat on jo munittu (ovat jo munitut)' 
466 | nаgлаd ebad vedud ol'bad 'nauloja ei oltu viety' 469 / vatja sa' unaz elivad $l i$ nad $\leftarrow$ ahettu 'Saunaan oli pellavat ahdettu' SUST 63 s. 106.

Vaikkakin vieras vaikutus on voinut suosia vanhassa kirjasuomessa ovat tehdyt-tyypin käyttöä, on kuitenkin todennäköistä, että juuri tämä tyyppi on alkuperäinen, sillä nykyisten passiivin liittomuotojen synty on tätä tietä parhaiten selitettävissä. Jos edellä esitetty käsitys yksinkertaisen passiivimme historiasta hyväksytään, voidaan liittomuotojen syntyä tuskin ajatellakaan muulla kuin tässä esitetyllä tavalla. Tätä käsitystä tukee edelleen - paitsi tyypin vallitsevuus vanhassa kirjakielessä — myös sen esiintyminen kansankielessä. Nomini on siis alkuaan ollut subjekti, ja on sanottu (minä) olen petetty, hän on petetty, te olette petetyt jne. Aluksi tyyppi tietenkin on tarkoittanut lähinnä vain tekemisen tuloksena olevaa tilaa (vrt. seinät ovat maalatut yms.). Sen kehittyminen myös itse tapahtumaa tarkoittavaksi, siis varsinaiseksi liittotempukseksi, on johtanut toisaalta apuverbin ja partisiipin suhteen tiivistymiseen, toisaalta taas apuverbin ja subjektin suhteen höltymiseen. ${ }^{6}$ Tämä kehitys on avannut yks. 3. persoonassa tien seuraaville muutoksille: Tyyppi on tehty on saanut yhä enemmän persoonattoman ilmauksen luonnetta, jolloin on tullut mahdolliseksi myös sellainen intransitiiviverbien käyttö kuin on lähdetty, on oltu jne. Transitiiviverbien ohessa taas on alkuperäinen subjekti (työ), jonka tarkoitteeseen verbin toiminta kohdistuu, alkanut puhujien kielitajussa rinnastua aktiivimuotojen objekteihin, mistä on ollut seurauksena, että sittemmin on alettu sanoa on tehty työtä, kirjat on luettu, minut on petetty jne. Subjekti on siis siirtynyt partisiipin objektiksi.

3. Tyyppi tÿ̈ on tehtävä.

On ilmeistä, että tässäkin tyypissä nomini (työ) alun perin on ollut subjekti ja että siis on sanottu sinä olet pelastettava, kirjat ovat luettavat jne. silloinkin, kun partisiippi on ilmoittanut tarpeellisuutta, välttämättömyyttä. Tällaista käyttöä esiintyy nykyään-

6 Tämä kehitys liittyy tietenkin vastaavan aktiivisen tyypin kehitykseen. Vieraiden kielten vaikutuksella lienee jotakin osuutta liittotempustemme kehitykseen (vrt. Eesti rahva etnilisest ajaloost, Tallinna 1956, s. 11, ArIStE), mutta tämä kysymvs kaipaa vielä tutkimista. 
kin, mm. paikallismurteissa. Esimm. jo olisivat kinnersuonet kitsustettavat, kantasuonet katsustettavat, kuin vaan vatsani vetäisi, syönnin aikaa suvattaisi Suomen kansan satuja ja tarinoita III22, Helsinki 1876, s. 11 / Virr Semmosia se hakee, jotk'ei olis haettavia SETÄLä LTKS § 197 / Kyl Kyllä siällä hyviä kiviä nys sano aluuks olevan seppä-Kustaa, mutta ne on sitte ostettavat heitiltä KanNisto LHLEH s. 187 / Pohj.-Savo Ne on toesen miehen tehtävät | Ne oeś Turusen ollu' tehtävät LATVALA LMPS $\$ 122$.

Tässäkin on ilmeisesti yks. 3. persoona välittänyt sen muutoksen, että ilmaustyyppi on tehtävä on muuttunut persoonattomaksi ja että alkuperäinen olla-verbin subjekti on siirtynyt partisiipin objektiksi. Tämän mukaisesti on ruvettu sanomaan on lähdettävä, on tehtävä työtä, kirjat on luettava, sinut on pelastettava jne.7

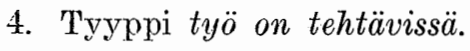

Tämän tyypin mainitseminen tässä yhteydessä tuntuu ehkä yllättävältä, sillä normaali ja korrektissa yleiskielessä kai ainoa mahdollinen jäsentymistapa on tässä sama kuin alkuaankin: työ on subjekti. Predikaatti on myös normaalisti kongruentti: työt ovat tehtävissä, olen tavattavissa jne.

Nykyään tapaa kuitenkin silloin tällöin seuraavanlaista käyttöä: Millainen oli sen ja sen eläinsadun alkumuoto, johon kaikki myöhemmät muodostukset on palautettavissa? US 31.3.1957, alakerta / Soittimia, jotka muistuttavat kiinalaista Cheng-soitinta, on It $\ddot{a}$ Aasiassa eri muunnoksina ja ne on lähinnä rinnastettavissa meidän harppuumme. UA 16.6.1957 / Ymmärrämme nyt, miten on selitettävissä omituiset säkeet, jotka tavataan Antero Vipusen virressä Vir. 1957 s. 359 / Luettelossa mainitaan, että kaikki nämä tuhatliunta julkaisua on tilattavissa Suomesta. US 4.10.1958.

7 Muututtuaan persoonattomaksi rakenne on tehtävä on sekä funktioltaan

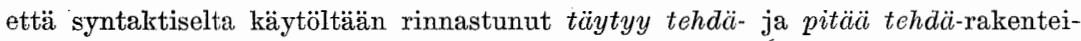

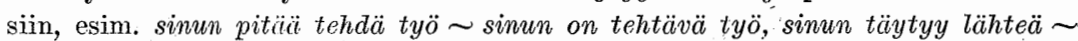
sinun on lähdettävä, vieläpä talouspolitiikassa on tapahduttava täydellinen mutos US 8. 3. 1957, murt. KosHl kaljaakin ol ain oltava RIITA SALMI Tutkimus Hämeen läänin Kosken vanhanaikaisesta ruokataloudesta ja siihen liittyvästä sanastosta (laudaturtutkielma 1956, Turun yliopisto) s. 198 (vrt. talossa pitäät. olla isäntä, keittod tulisi olla heti valmiina, ks. Trowa Vir. 1954 s. 210 ym.). Viimeksimainitunlaista käyttöä, jossa on oltava-rakenteeseen liittyy subjekti, on pidetty virheellisenä (ks. esim. KaArlo Nisminen Vir. 1950 ss. 197-198). 
Useimpien näiden kohtien kirjoittajat ovat tunnetut hyviksi kielenkäyttäjiksi, joten näissä ei ymmärtääkseni ole kysymys pelkästä satunnaisesta subjektin ja predikaatin inkongruenssista. Todennäköisesti nämä selittyvät siten, että kirjoittajat ovat tajunneet on tehtävissä-tyyppisen rakenteen persoonattomaksi (= voidaan tehdä), jolloin alkuperäinen subjekti on joutunut objektin asemaan. ${ }^{8}$ Läheisen. analogiamallin on tarjonnut tyyppi on tehtävä: kun sanotaan muodostukset on palautetava, on helposti syntynyt ilmaustyyppi muodostukset on palautettavissa.

Jäsentymisen siirtyminen on tässä vasta idullaan, mutta tämä tapaus valaisee edellisen tyypin kehitystä ja osoittaa samalla, miten eri-ikäisetkin syntaktiset siirtymät voivat olla keskenään syyyhteydessä.

5. Tyyppi työ tulee tehdyksi ( tehty ä).

Alkuperäinen jäsennys on tässäkin sellainen, että tÿ̈ on subjekti. Tällöin tietenkin predikaatti (ja osittain predikatiivikin) kongruoi: tulin pelastetuksi, työt tulivat tehdy(i)ksi. Länsimurteissa on laajalti käytännössä tyyppi, jossa II partisiipin translatiivin tilalla on partitiivi, esim. VesL Minä tuli haavotettua ennej jo KanNisto LHLEH s. 238.

Sekä yleis- että kansankielessä käytetään po. tyyppiä nykyään yleisesti myös persoonattomana, jolloin alkupexäinen subjekti on partisiipin objektina. Esimm. elämän arvoja tulee iltaisin kapealla vuoteella uudestaan mitatuksi. Uusi Kuvalehti 1958 n:o 41, s. 4 / Minun tuli siinä kiireessä selitetyksi asia huonosti PENTrLL̈̈ SK \$471 / Keu Ei o' koskaan nïtä tullu' tarvituks / Ruov Nyt tuli tollaiset tyät tehtyä SETÄLÄ LTKS §§ 244-245 / Pom Ei oo tullu' niitä poikki pannuks lalvoista / MerK Vallan tulee piðettyy pyhä̈ LA'rvaLA Lauseopillisia havaintoja Luoteis-Satakunnan kansankielestä, Suomi III 12, §157 / Pohj.-Savo Kyllähän sitä ee paljoo tullu' tehyles Latrvala LMPS §123 /. Risna ei oo tulluna nïtä oikei esityks PAAsONEN Lauseopillisia havaintoja verbin ja konjunktionein alalta, Suomi III 3, §27 / Urj Ei ot tullus siẗ̈ tapal otettua Kannisto LHLEH s. 238.

8 Vielä kiistattomampi on siirtymä seuraavassa: Vaikka uiudelle puolueelle itselleen ei sïs voidakaan hankkia edustajapaikkoja, sen avulla kenties on heikennettävissä maalaistiiton asemaa eduskunnassa. Maakansa 11.2.1959. 
Siirtymisen tapahduttua on myös intransitiiviverbien käyttö tässä rakenteessa tullut mahdolliseksi; silloin ei alkuperäisellä subjektilla ole lainkaan jatkajaa. Esimm. Minun tuli sanotuksi vähän

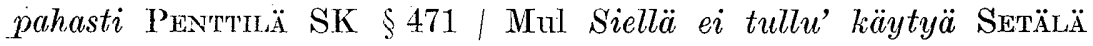
LTKS $\S 244 / \mathrm{Kyl}$ Jokos tuli mentyä raittiusseuraa? KaNNIs'ro LHLEH s. 238 / Pohj.-Savo T'ulloo minultae' käövyks Latvala LMPS § 123 / Jää-Kir Ei miult tullt sinne reisutuks SiRELIUs LTJK $\S 119$.

6. Tyyppi työ tulee tehtäväksi.

Alkuperäistä kantaa edustaa se nykyäänkin yleinen tyyppi, jossa työ on subjekti ja tulee sen mukaan kongruoiva predikaatti: tulen kastettavaksi, työt tulevat tehtäväksi (tehtäviksi) jne. Esimm. nijn keskusteldin, millä tavalla permando puut tulevat tuotavaxi Lizelius 1757, Vir. 1919 s. 61 / Virr Ei se tule maksettavaks SETÄLÄ LTKS $\S 243$ / (Kaav-)Jor kyllä tuota työ tulette vietäväks kesker ruok aejan KeTruneN Suomen murteet I, Helsinki 1930, 62:14- / JääKir Nä̈ tulloot kaikk pois otettaviks SiRecius LTJK § 214.

Tämän alkuperäisen tyypin rinnalla esiintyy sekä vleiskielessä että paikallismurteissa tyyppi, jossa ilmaus tulee tehtäväksi on mututunut persoonattomaksi ja alkuperäinen finiittimuodon subjekti siirtynyt partisiipin objektiksi. Esimm. Nyt seurais eläinten ruan enäntämisestä ja kokomisesta, jos tulewana Wuonna näitä Tieto-Sanomita tulee annettawaxi ulos. Suomenkieliset Tieto-Sanomat 1776 s. 186 / Silloin tulee sanottavaksi ilman yhtään vilppiä ja viekastusta: tässä olen minä ja — - Kivi KT I s. 130 / Virr Tulee peetä ärrän kans yhteen sovitettavalss (= kirottavaksi) / Tulee hakattavaks semmosta mehtää, josta tulis tukkia SETärä LTKS §243 / Ylö Meiltä tulee kansa hävitettäväks pari lehmää syyspualella talvee IRJA KETONEN Tutkielma nominaalimuotojen käytöstä Ylöjärven murteessa (laudaturtutkielma 1948, Turun yliopisto) s. 47 | Aka "Meirän" sanotaan tässä, jos semmosta sanaa tulee sanottavalss KanNisto LHLEH s. 240 / Jää-Kir Nyt täss tuliškii paljo töitä tehtäväks SIRELuUs LTJK § 214.

Myös intransitiiviverbien käyttö rakenteessa on täten tullut mahdolliseksi. Esimm. Sen jälkeen, ja että asiat, joista tulisi neuoteltavaksi, kohta alusta järjestyksellä käsitettäisiin, Lönnrot 1831, Suomen kansalliskirjallisuus XI s. 471 / _ - vaikka eräitä saman- 
aikaisia tunnetaankin, kuten edempänä tulee mainittavaksi. Rapola, Vanha kirjasuomi s. 8 / Keu Tottapa sitä tul' lähettäväks SEт̈̈rä

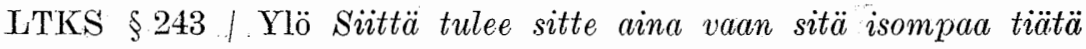
mentävä7s KETONEN mt. ss. 47-48/ Kyl Ei se mitääv vastaaj (nim. takauksia) jos nïstä vastattavaks tulee KNNNisto LHLEH s. 240 / Pohj-Savo Tullooko sitä tultavaks tänne: vielä? Latvala LMPS $\S 122$ / Jää-Kir Tullooks teilt millo Viipurii lähettäväks? SrRELIUs LTJK §214. (Vrt. IKoLA TMK I s. 235-)

7. Tyyppi työ kuuluu tehtävän t. tehdyn.

Tässäkin tyypissä on nomini (työ) alkuaan kaikesta päättäen ollut finiittiverbin (kuulua, näkyä, näyttää, tuntua) subjekti. Alkuperäinen tyyppi lienee ollut työ kuuluu tehtävä, työt kuuluvat tehtävä $(t)$ (vrt. OJANsuU MAK s. 154). Nykyään sen sijaan nomini käsitetään partisiipin objektiksi ja lauseen predikaatti on persoo-

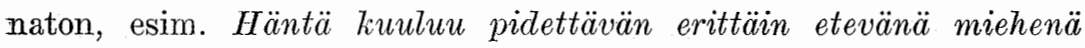
SEт̈̈LÄ SKL $§ 120$ / Sinut näkyi asetetun ensi tilalle HAKULINEN SKRK II s. 266 / Teille kuuluu tuodun uusi emäntä PENTTILÄ SK $\$ 456$.

Näin on tullut mahdolliseksi myös intransitiiviverbin partisiipin käyttö, jolloin alkuperäisellä finiittimuodon subjektilla ei ole lainkaan edustajaa, esim. Nyt näyttää lähdettävän / Talossa näkyy herätyn PentrTIL̈ SK $\S 456.9$

\section{Finiittimuodon subjekti siirtynyt infinitiivin objektiksi}

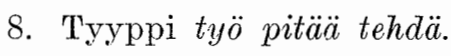

Tätä tyyppiä käytetään verbien täytyy, pitää, tulee, tarvitsee, sopii, kelpaa jne. yhteydessä (täydellisempi luettelo kysymykseen

9 Partisiipin ollessa aktiivinen ei siirtymistä ole tapahtunut, vaan nomini käsitetään edelleen finiittiverbin subjektiksi, esim. Venäläiset kunluvat päljon rakastavan teetä / Sanoitko, että minä näytin olevan vihoissani? SETÄÏ̈ SKL $\$ 120$ / transl.: Suru sorti suuren äänen, huoli armahan alenti; sill' ei kwulu Jcuk7cuvaksi, päivän laskun laulavaksi KaJ. 5: 202—. Tosin nykyisessä kirjakielessä käytetään seuraavanlaistakin tyyppiä: - -- sain tietooni saksalaisen käskyn, josta ilmeni Hitlerin päättäneen, että - - Mannerheim IT s. 348. Tässä on persoonattomasti käytetyn intransitiiviverbin subjektiksi analogisesti tullut samantyyppinen partisiippirakenne, kuin esiintyy transitiiviverbin objektina (vrt. hän ilmoitti $\mathbb{Z}:$ n pä̈̈ttäneen). 
tulevista verbeistä: PeNTTu LÄn antaman selityksen mukaan on nomini (työ) alkuaan ollut. finiittimuodon subjekti, kun taas infinitiivi on ollut predikaatin. määrite. Transitiivisen verbin infinitiivi on ollut tässä rakenteessa.

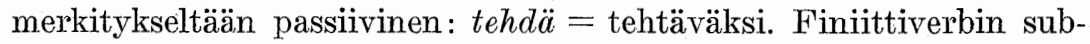
jekti $(t y \ddot{o})$ on sittemmin siirtynyt tämän infinitiivin objektiksi.. Siirtymisen ovat tässäkin kaikesta päättäen välittäneet sellaiset. tapaukset, joissa predikaatti on ollut yks. 3. persoonassa, so. tavallisimmassa muodossaan. Tämän siirtymisen tapahduttua on tyyppiin.

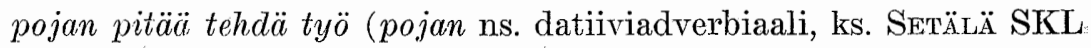
$\S 30,6$ ) voitu sijoittaa intransitiiviverbinkin infinitiivi: pojan pitäă. menn $\ddot{a} .^{10}$

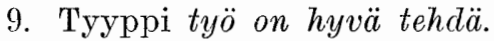

Alkuperäistä jäsentymistä kuvastaa vielä esim. lause hän on launis katsoa (hän subj., katsoa predikatiivin määrite, merkitys suunnilleen 'katsottavaksi'). Mutta nykyään ovat yleisiä sellaiset. sanonnat, joissa lauseen alkuperäinen subjekti on siirtynyt infinitiivin objektiksi, esim. on hyvä tehdä työtä, on vaikea saada kaloja. Väliasteena ovat olleet sentapaiset kuin velka on hyvä maksaa on

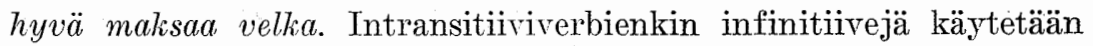
nykyään samalla tavoin, esim. on mieluista lähtë̈ '(ks. SEтÄLÄ SKL §30,6; HakULINEN SKRK II s. 239).

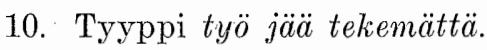

Alkuperäistä jäsentymistä, joka tässä tyypissä on nykyäänkin vallitseva, edustaa mm. lause Puut jäivät pilkkomatta NS 2 s. 110. Nykyään on kuitenkin mahdollista sanoa myös minulta jäi pilkkomatta puita (= minulta jäi puiden pilkkominen), jolloin puita on lähinnä käsitettävä III inf:n objektiksi. Seuraava murre-esimerkki edustanee mainitunlaista siirtynyttä jäsentymistä: KuoV kyllä se jäi saamatta sev velkamiehev velat SS Ritva Peltonen 1948. Siirtyneestä jäsentymisestä on joka tapauksessa kysymys seuraavissa.

10 Jos alkuaan oli kyseessä intransitiiviverbin infinitiivi, ei finiittiverbin. subjekti tietenkään voinut siirtyä inf:n objektiksi, vaan se joutui inf:n subjektin asemaan, esim. talossa pitää olla isäntä (lähemmin ks. IxorA Vir. 1954 s. $233-)$. 
esimerkeissä, joissa infinitiivi on intransitiivinen ja joista kokonaan puuttuu alkuperäisen subjektin jatkaja: KanN Jäe multaes Sammal'lahella käömätä' SS O. Kuitunen 1924 / Jää-Kir Manmalt taiś jäähä tulemata täll kesäll Jääskee SirELIUs LTJK § 119. Tällainen ilmaustyyppi on kielitajuni mukaan mahdollinen kirjakielessäkin, vaikka minulla ei satu olemaan siitä selviä esimerkkejä.

\section{Finïttimuodon objekti siirtynyt passiivisen partisiipin objektilisi}

\section{Tyyppi saan työn tehdyksi ( tehtyä).}

Tässä tyypissä on nomini (työn) alkuaan jäsentynyt finiittiverbin objektiksi, jolloin pass. II partis :n translatiivi on ollut predikatiiviadverbiaali. Monessa tapauksessa tämä tyyppi jäsentyy nykykielessäkin näin, mutta tavallista on toisaalta sekin, että nomini on joutunut partisiipin objektiksi, esim. Sain sanotuksi tärkeimmät seikat / Saitko otetuksi roskan silmästä? PeNtmiLä SK s. 358 / Ne vähäiset viemiset, joita saatiin kerätyksi ja säästetyksi yli oman tarpeen Merenmaa, Mustan kukon laulu ${ }^{4}$ s. 13 / Aina kun Helmi sai hetken aikaa ajatelluksi jotakin, alkoi joku lapsista kitistä. Joenpelto, Neito kulkee vetten päällä 5 s. 152 / Näin saadaan maiden multavuutta ja viljavuutta tehokkaasti lisätyksi, Uusi Kuvalehti 1957 n:o 11, s. 25. Esim. länsimurteissa esiintyvästä partitiivin käytöstä: Ruov Akka sai lehmän varraastettua SkTäLä LTKS $\S 244$.

Alkuperäisen jäsentymistavan vallitessa ovat kysymykseen tulleet vain transitiiviverbien partisiipit, mutta siirtymisen tapahduttua on tullut mahdolliseksi intransitiiviverbienkin partisiippien käyttö tässä. ilmaustyypissä, jolloin finiittiverbin alkuperäisen objektin jatkaja kokonaan puuttuu, esim. En saanut nukutuksi SETÄLÄ SKL §119 I 4d / Hän sai lähdetyksi noutamaan sen viereisestä huoweesta Simenon, Maigret ja vanha rouva (suomennos) s. 157 / Rym se niim pal pakotti ja poltti etei saanum maatuks ei istutuks 11 O. Ikola 1952 ! Kuru Se sai nojattua SETÄLÄ LTKS \$ 244.

11 Lounaismurteet ovat tässä tyypissä osaksi translatiivin kannalla, vaikka länsimurteissa muuten enimmäkseen on partitiivi. 
Tässä tyypissä on siis tapahtunut sellainen muutos, että finiittiverbin objekti on siirtynyt passiivin II partisiipin objektiksi. Jos lauseen predikaatti on ollut passiivinen (työ saadaan tehdyksi), koskee siirtyminen oikeastaan alkuperäistä subjektia. Tämä ja seuraavissa kohdissa käsiteltävät siirtymiset niveltyvät näin ollen hyvin läheisesti edellisiin (vrt. kohtaan 5: tÿ̈ tulee tehdyksi).

12. Tyyppi määrään työn tehtäväksi.

Erikseen on käsiteltävä tätä tyyppiä, jossa lauseen predikaattina tavallisimmin on jokin verbum voluntatis ja jossa siitä syystä tulee kysymykseen vain pass. I partisiipin translatiivi (ei siis II partis. eikä partitiivi). Tässäkin on nomini alkuaan ollut finiittiverbin objekti, ja monessa tapauksessa rakenne jäsentyy nykyäänkin näin, esim. Tuomari määräsi pidätetyt kuulusteltaviksi. Mutta yleisiä ovat myös sellaiset esimerkit, joissa nomini täytyy käsittää partisiipin objektiksi, esim. ne Kyntiläkruunut, cuin Kirlan Kocouxesa v. 1757 s. 1. p. marras cuusa, päätettin ostettavaxi, - - - ovat nyt Stockholmista toimitetut Turcuun, Lizelius 1758, Vir. 1919 s. 64 | Olin - - - esittänyt, että lähetystön henkilökuntaa ehdotettaisiin vähennettäväksi Mannerheim II s. 340 / Ahlqvist vaati myös partisiippirakenteen predikatiivin ilmaistavaksi akkusativvilla. Kohtamäki, Ankara puutarhuri s. 154 / tuomarikunta päätti palkinnon annettavaksi - - Kullervon tekijälle, Ibid. s. 261 / Pakistan on ehdottanut $Y K: n$ joukkoja lähetettäväksi Kashmirïn UA 4.2. 1957 | molemmat osapuolet hyväksyivät sopimuksen irtisanomisaikaa sïrrettäväksi kolmella kuukaudella. US 1. 10.1958 | Budjetissa ehdotetaan perustettavaksi tarpeelliset virat ja toimet. UA 3.10.1958 / Koulujen syksyn väliarvostelu suunnitellaan poistettavaksi. UA 24. 10. 1958.

Tässäkin tyypissä voidaan nykyään käyttää intransitiiviverbienkin pass. partisiippeja, jolloin alkuperäistä finiittimuodon objektia vastaava lauseenjäsen kokonaan puuttuu, esim. Mutta kun Jeesus näki paljon kansaa ympärillään, määräsi hän lähdettäväksi toiselle puolelle. UT 1913, Matt. 8:18/ — - hän oli lä̈skenyt hyäkättäväksi Mikkelin kautta Pielssämäelle. Mannerheim I s. 305 | - Hitler oli — - _ esittänyt ryhdyttäväksi toimenpiteisiin tuon toiminnan ehkäisemiseksi. Ibid. II ss. 337- 1- - oli jaksanut ja ymmärtänyt päättä̈ ryhdyttäväksi idässä taisteluun. Ibid. II s. 406 
I Lehden tietojen mukaan Hrushtshev määräsi tapauksesta vaiettavalsi. Turun Sanomat 17.11. 1958.

Tätä ilmaustyyppiä olen seikkaperäisemmin käsitellyt kirjoituksessani "Eine finnische Partizipialkonstruktion" (UAJb XXVIII ss. 201-202). Näyttää kuitenkin siltä, ettei tämä tyyppi sittenkään ole niin nuori, kuin mainitussa kirjoituksessani olen otaksunut. (Vxt. kohtaan 6.)

13. Tyyppi näen työn tehtävän ( tehtäväksi) t. tehdyn ( tehdyksi).

Tässäkin tyypissä on nomini (työn) alkuaan ollut finiittimuodon objekti, mutta siirtynyt sitten partisiipin objektiksi. Esimm. Olen kuullut häntä paljon kïtettävän | Isäntä sanoi asiasta huomenna lähetettävän tiedon kirkolle SETÄLÄ SKL \$120 / Kalan pyytäjä - kertoi hänen nuoruudessaan kuivattua haukea yleisesti syödyn - Oma maa 3, 1958, s. 68. Puheena oleva lauseenjäsen on alkuperänsä mukaisesti vielä nykyäänkin muodoltaan riippuvainen lauseen predikaatista: Mies kertoi kylän takamailla ammutun ison karhun Kerrotaan kylän takamailla ammutun karhu.

Tässäkin on jäsentymisen siirtyminen johtanut myös intransitiiviverbien pass. partisiipin käyttöön, esim. Kyllä isä tiesi kirkolla käydyn SEväLä SKL § 120. (Vrt. kohtaan 7.)

Milloin partisiippi on translatiivissa (näen työn tehdyksi jne.), on alkuperäinen jäsentyminen nykyäänkin usein mahdollinen. On kuitenkin myös sellaisia tapauksia, joissa jäsentymisen sirtyminen tällöinkin on selvästi todettavissa, esim. Johan Kuuskoski sanoi kyllä cuullensa hohutuxi, cuin olis se keskimäinen kipiä lapsi cuollut Lizelius 1756, Vir. 1919 s. 59 / Ainoastansa yhdessä paikassa (- - osoitetaan Pohjolassa outoa kieltä puhutuksi Lönnrot, Uuden Kalevalan esipuhe / kuuli kummia sanoja, lauluja laeltavaksi, parempia pantavaksi Kal. 3:24- | Noin kuulin saneltavaksi, tiesin virttä tehtäväksi: Kal. 1:103- Tällainen translatiivin käyttö kuuluu enimmäkseen jo vanhentuneeseen kieleen.1.2

12 Partisiipin ollessa aktiivinen (näen pojan menevän moneväksi) on alkuperäinen finiittimuodon objekti (pojan) siirtynyt partisiipin subjektin asemaan. Alkuperäinen objektin sija on silloin säilynyt merkitykseltään eksistentiaalisissa rakenteissa (esim. näin vieraita tulevan), kun taas muissa tapanksissa sen tilalle on yleistynyt genetiivi (ks. IKoLA Vir. 1954 ss. 212, 231-, 234). 
V. Finïttimuodon objekti sïrtynyt infinitiivin objektiksi

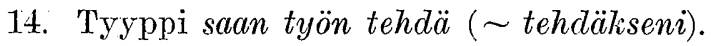

Verbeihin aikoa, haluta, koettaa, luvata, pyytää, saada, tahtoa, tietäa yms. liittyy usein I infinitiivi, jonka subjektipersoona on sama kuin hallitsevan verbin (ks. SErÄLÄ SKL §112 V a). Kysymykseen tulevat verbit kuuluvat ns. modaalisiin verbeihin (ks. Sizo Vir. 1951 s. 391; Pentrmä SK § 443). Ainakin osaksi nämä rakenteet palautuvat sellaiseen alkuperäisempään tyyppiin, jossa nomini (työn) on ollut finiittimuodon (saan) objekti (ei siis inf:n objekti, joksi se nykyään käsitetään). Lause saan työn tehdä on siis alkuaan merkinnyt: 'saan työn tehtäväkseni' (vrt. SEт̈̈L̈̈ SKL § 30,6). Toisinaan, etenkin murteittain, esiintyy tällaisessa käytössä myös I inf:n pitempi muoto. Seuraavat esimerkit kuvastavat vielä alkuperäistä jäsentymistä: Pojat eivät edes saaneet häntä nähdäkseen, Talvio, Itämeren tytär s. 14 / Ruov Ne rupesivat tahtoon sitä lakkia ostaakseen | Keu Se pyyś mehteä mult ostoakseen / Se tahtos sitä nähäkseen SETÄLÄ LTKS § 35 / Pälkä pyys sitte hevosta saalakscen VIR'TARANTd Hämeen kansa muistelee s. 224.

Finiittimuodon objektin siirryttyä inf:n objektiksi (tavallinen sanajärjestys: saan tehdä työn) on tähän tyyppiin sopinut myös intransitiiviverbin infinitiivi, jolloin alkuperäisen objektin edustaja kokonaan puuttuu, esim. tahdon lähtë̈. Tällaisissakin tapauksissa saattaa esiintyä I inf:n pitempi muoto, esim. Toiset lupasivat7in kotona pysyälisensä; Suomen kansan satuja ja tarinoita $I^{2}$, Helsinki 1871, s. 19 / Ja niin olivat Matti ja Liisa päättäneet lähteäkseen rautatiellä ajamaan. Aho, Valitut teokset, Porvoo 1953, s. 78. Eräissä tapauksissa on verbin merkitys muuttunut niin, ettei alkuperäinen jäsennys enää ole yhtä helposti tajuttavissa kuin äskeisissä esimerkeissämme. Asia ei kuitenkaan liene niin, että kaikki ne tapaukset, joissa modaaliseen verbiin liittyy I inf., olisivat yllä esitetyllä tavalla selitettävissä. Toisena tämän ilmaustyypin lähtökohtana ovat voineet olla jotkut sentapaiset sanonnat kuin menen maata (= makaamaan), vrt. aion maata, haluan maata.

15. Tyyppi annan työn tehdä.

Verbeihin antaa, sallia, käskeä yms. liittyy usein I inf:n lyhyempi muoto, jonka subjektipersoona ei ole sama kuin hallitsevan 
verbin. Tyyppi annan työn tehdä. on alkuaan jäsentynyt niin, että nomini (työn) on ollut finiittimuodon objekti. Infinitiivin subjektipersoona on voitu ilmaista datiivigenetiivillä. Esim. lause annan pojan tehdä työn on siis alkuaan ymmärretty näin: 'annan työn pojalle tehtäväksi' (ks. SEräLä SKL § 30,6). Finiittimuodon objekti on tässäkin siirtynyt infinitiivin objektiksi. ${ }^{13}$

16. Tyyppi otan työn tehdäkseni.

Nomini (työn) on tässäkin tyypissä kaikesta päättäen ollut finiittimuodon objekti, joksi se vieläkin monessa tapauksessa voidaan käsittää, esim. Seppä otti työn tehdälsensä SEräLä SKL §113 I Muist. 2 ! Otin käännöstyön tehdäkseni Pentrtü̈ SK §327, 4.

Yleisempiä kuitenkin ovat sellaiset tapaukset, joissa on tapahtunut jäsentymisen siirtyminen: alkuperäinen finiittimuodon objekti on siirtynyt infinitiivin objektiksi. Esimm. ja otti Herra Professori Linsén häneltä tätä kysyälssensä ja antaa 14 Seurallen siitä tiedon. Lönnrot 1831 (Suomen kansalliskirjallisuus XI s. 473)/Oletpa ottanut nähdäksesi suuren vaivan NS 4 s. 128 / Aluksi Kaukonen on siinä ottanut pohtiakseen eräitä perustavia näkökohtia, niiden joukossa mri. kansanrunouden ja Kalevalan suhdetta Vir. 1956 s. 405 / hän otti pitkään selittääksensä nuorelle kä̈̈nnynnäiselle, miten turha ja ennenaikainen moinen yritys olisi ollut Rapola, Risukoista riipomia s. 11 / KuoV ja monen aikasta juttua kuulee mutta em min̈̈ ok kaikkia ottanum muistaaksenitan SS Ritva Peltonen 1948.

Samalla tavoin käytetään nykyään intransitiiviverbienkin I inf:n pitempää muotoa, jolloin alkuperäistä finiittimuodon objektia vastaava lauseenjäsen puuttuu: Ostajan on otettava vastatakseen tilan kïnnityslainoista | Väkijouklo ei ottanut hajaantuakseen / Ovi ei ota avautuakseen NS 4 ss. 127-128 / Tampereen seuduilla on eräs seurakuntakin ottanut asiasta huolehtiakseen Uusi Kuvalehti 1959

$13 \mathrm{~J}$ os kyseessä oli intransitiiviverbin infinitiivi (esim. annan pojan mennä), on alkuperäinen finiittimuodon objekti joutunut inf:n subjektin asemaan. Alkuperäinen objektin sija on säilynyt tällöin vain infinitiivirakenteen ollessa merkitykseltään eksistentiaalinen (esim. annan ammeeseen valua vettä), mutta muuten sen tilalle on yleistynyt genetiivi. Tämän yleistymisen on aiheuttanut toisaalta päkitteellisen yks. akkusatiivin ja gènetiivin identtisyys, toisaalta annan pojan tehdä työn-tyypin datiivigenetiivin (pojan) analogia (vrt. IKoLA Vir. 1954 ss. $210--, 231-, 234-)$.

14 Huom. I inf: n lyh. muoto. Vit. edemp. 
n:0 2 s. 24 / Hallitusasia ei ota edistyäłseen. Uusi Päivä 10.1.1959 / PyhR ei se ottan oikke luanistakses [onnistuakseen] SS Saini Laurikkala 1927 / Vam ettei ollenkam meinaap parantuaksens ottaa SS Eino Lepistö 1939 / Nas nyt on oraat ottaniet vähän kasvaaksien SS Martti Rapola 1923 / Juv minä ku oti siitä vähä nuoi hävetälisei SS Arvo T. Inkilä 1936. Olịi vaikea ymmärtää tätä I inf:n käyttöä, ellei ajatella sen syntyneen rakenteista, joissa ottaa-verbillä on ollut objekti.15

Kansanrunoudessa ja paikallismurteissa esiintyy $\mathrm{I}$ inf:n pitemmän muodon tilalla tässä rakenteessa toisinaan lyhyempi muoto, esim. kun ottaisi kolmitse sitä lampia miekalla ristiin lyödä, Suomen kansan satuja ja tarinoita II, Helsinki 1854, s. 15 / Ei ota vene

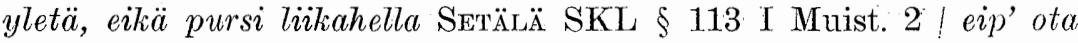
olut hapata, juoma nuori noustaksensa Kal. 20:249-/ KarL kun ei se hevonen ota tiellä pysyä SS Hj. Anthoni 1900 / KanA Kyllä

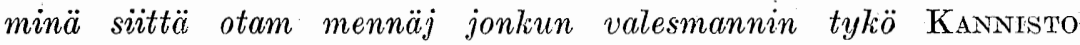
LHLEH s. 212 | Mou ne ottas tiätäv [haluaisivat saada tietää] vähä vanhanaikasia asioita. SS Ilmari Kohtamäki 1934; possessiivisuffiksillisenakin: KanA kaikli sano että mull on sisällinev vaiva ja on ottanut tullansa ulos KanNisto THLEH $\$ 94 \mathrm{I}$.

Tässä kohdassa käsitelty siirtyminen liittyy läheisesti kohdassa 14 käsiteltyyn.

17. Tyyppi jätän työn tekemättä.

Tämän tyypin alkuperäinen ja nykyäänkin yleinen jäsentymistapa on sellainen, että nomini (työn) on finiittimuodon objekti. Mutta esiintyy myös sellaista jäsentymisen siirtymiseen perustuvaa käyttöä, jossa nomini on käsitettävä III infinitiivin objektiksi tai josta alkuperäistä objektia edustava lauseenjäsen puuttuu, esim.

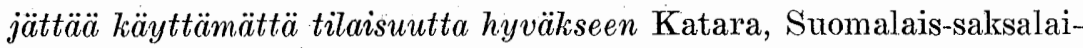
nen sanakirja 3 s. 210 / jättää tulematta / jättää kostamatta NS 2 s. 107 | Edellä olen jättänyt kertomatta eräistä hankauksista, Mannerheim II s. 101.

15 Virolaisessa kansanrunoudessakin on seuraavanlaista käyttöä: Ei votand Peter Kuulakseni, Eigä Pavel luulakseni Eesti Rahvalaulud I, Tartto 1926, s. 297. Tässä on 1 . persoonan suffiksi yleistynyt. Ks. JULuUS MARK SUST 54 § $29-$ ja SUST 58 s. 191. 
Tässäkin on siis finiittimuodon objekti siirtynyt infinitiivin. objektiksi (vrt. kohtaan 10).

Kun passiivin finiittimuodon subjekti on siirtynyt objektin asemaan, on verbimuoto jäänyt subjektittomaksi ja tullut persoonattomaksi (kohta 1). Kaikille muille edellä käsitellyille tapauksille (kohdat 2-17) on yhteistä se, että finiittimuodon subjekti tai objekti on siirtynyt infiniittimuodon objektiksi. Tämän siirtymisen tapahduttua ei mainittu lauseenjäsen enää ole missään näistä tapauksista. rakenteen välttämätön osa, vaan sen puuttuminenkin on mahdollista. Milloin siirtyminen on koskenut alkuperäistä subjektia (kohdat. 2-10), on rerbi-ilmaus samoin kuin 1. kohdassakin jäänyt subjektittomaksi ja tullut persoonattomaksi. Muutkin tapaukset (kohdat 11-17) liittyvät läheisesti edellisiin. Voitaisiinpa ne lukea edellisten kanssa suorastaan samaan ryhmäänkin silloin, kun finiittimuoto on passiivinen: silloin on siirtyminen niissäkin oikeastaan koskenut alkuperäistä subjektia.

Edellä esitettyjen tapausten lukumäärä osoittaa, että kysymys on sangen laaja-alaisesta syntaktisesta siirtymistendenssistä. Nämä eri tapaukset ovat osaksi varmaan rinnakkaisia, mutta osaksi taas niiden suhde lienee sellainen, että jokin tai jotkin tapaukset ovat vetäneet perässään muita ilmaustyyppejä saman tendenssin piiriin. Tällaiset siirtymiset ovat muuttaneet kielen rakennetta mm. siinä suhteessa, että infinitiivit ja passiivin partisiipit ovat saaneet objektin, mikä alkuaan ei ole ollut mahdollista.

Olen hyvin selvillä siitä, ettei esitykseni riitä tyhjentävästi selvittämään käsiteltyjen ilmaustyyppien historiaa. Esim. vanhan kirjasuomen ja sukukielten tarkempi tutkiminen toisi varmaan lisävalaisua asiaan. Minulta on voinut myös jäädä huomaamatta joitakin sellaisia siirtymiä, jotka ovat samaa lajia kuin edellä käsitellyt. Tarkoitukseni on ollut ennen kaikkea huomion suuntaaminen näihin. liian vähän tutkittuihin syntaktisiin ilmiöihin.

Osmo IKoLA: Über einige syntaktische Verschiebungen im Finnischen

Verf. behandelt einige finmische Ausdruekstypen, bei denen seiner Auf: fassung. nach folgende syntaktische Verschiebungen stattgefunden haben: das. 
Subjekt einer passiven finiten Form ist Objekt derselben Form geworden oder das Subj. bzw. Objekt einer finiten Form ist zum Obj. eines Infinitivs oder passiven Partizips versehoben.

I. Verschiebung des Subjekts einer passiven finiten Form zum Objekt derselben Form. 1. Typ työ tehdään 'die Arbeit wird getan'. J. von F'ARKas äusserte vor einigen Jahren die Ansicht, das finn. Passiv sei ursprünglich, ebenso wie in der heutigen Sprache, unpersönlich gewesen (UAJb XXVIII S. 261). Verf. kommt jedocl: im vorliegenden Aufsatz zu dem Ergebnis, das finn. Passiv sei - wie bisher allgemein angenommen (SETÄLÄ, OJANSUU, HakUlinen u.a.) früher persönlich gewesen. Das Satzglied $(t y \ddot{o})$, welches heute als Objekt der passiven Form aufgefasst wird, ist demnach ursprünglich Subjekt gewesen.

II. Verschiebung des Subjekts einer finiten Form zum Objekt eines passivcn Partivips. 2. Typ työ on tehty 'die Arbeit ist getan (worden)'. Das Nomen (työ) war ursprünglich subjekt, das Hilfsverb (on) (verbales) Prädikat und das Partiz. II (d.h. Perf.) Pass. (tehty) Prädikativ (nominales Prädikat). Es hiess also: kirjat ovat luetut 'die Bücher sind gelesen', (minä) olen petetty 'ich bin betrogen' usw. - Infolge der am häufigsten verwendeten $3 . \mathrm{Sg}$. haben sich die Begriffe verändert, so dass der Ausdruck on + Partiz. II Pass. unpersönlich wurde und das ursprüngliche Subjekt als Objekt des Partizips aufgefasst wurde. Es hiess infolgedessen: on tehty työtä 'man hat gearbeitet', Jirjat on luettu 'man hat die Bücher gelesen', minut on petetty 'man hat mich betrogen' usw. - Das zum. Objekt des Partizips verschobene Wort (työ) hat jedoch hier wie auch in folgenden Fällen (mit Ausnahme einiger Pronomina) den Subjektkasus beibehalten. - 3. Typ työ on tehtävä (Partiz. I [d.h. Präs.] Pass.) 'die Arbeit ist zu tun, d.h. muss getan werden'. Ursprünglich sagte man: 7irjat ovat luettavat 'die Bücher sind zu lesen(de)', sinä olet pelastettava'du bist (ein) zu retten(der), d.h. musst gerettet werden' usw., heute wird jedoch meistens gesagt: 7iirjat on luettava 'man muss die Bücher lesen', sinut on pelastettava 'man muss dich retten', on levättävä 'man muss sich ausruhen' usw. 4. Typ työ on tehtäivissä (Partiz. I. Pass. Iness. Plur.) 'die Arbeit kann ausgeführt werden'. In der korrekten Gemeinsprache besteht auch heute die ursprüngliche Art dex Gliederung, wonach das Nomen (työ) das Subjekt darstellt. Hie und da sieht man jedoch den unpersönlichen, dem vorhergehenden Fall ähnlichen Gebrauch dieses Typs: työt on (pro ovat) tehtävissä 'es ist möglich, die Arbeiten auszufuihren' usw: - 5. Typ työ tulee tehdyksi (Partiz. II Pass. Transl., mundartlich auch Partit. tehtyä) 'die Arbeit wird ausgeführt (werden)'. Anfangs hiêss es: tulin pelastetuksi 'ich wurde gerettet', työt tulivat tehdy(i)ksi 'die Arbeiten wurden ausgeführt' usw. Heute wird dieser Typ allgemein auch unpersönlich gebraucht, z.B. minun tuli tehdyksi työ huonos schlecht ausgeführt', ei tullut lähdetylssi 'man kam nicht zum Gehen'. - 6. Typ työ tulee tehtäväksi (Partiz. I Pass. Transl.) 'die Arbeit wird getan werden'. Ursprünglich hiess es: työt tulevat tehtävälssi (tehtäviksi) usw., heute ist jedoch folgender Gebrauch allgemein: tulee tehtäväksi työtä, 'es wird gearbeitet werden', tulec levättäväksi 'man wird sich ausruhen'. - 7. Typ työ kuuluu tehtävän bzw: tehäyn (Partiz. I bzw. II Pass. Akk: Sg.) 'die Arbeit soll getan wer- 
den bzw. worđen sein'. Das Nomen. (työ), anfänglich Subjekt der finiten Form, wird heute als Objekt des Partizips aufgefasst, das Prädikat ist unpersönlich, z.B. teille kunluu tıodun unsi emäntä' 'es soll euch eine neue Wirtin ins Haus gebracht worden sein', nyt näyttää lähdettävän 'es scheint, dass jetzt aufge'brochen wird'.

IIT. Verschiebung des Subjekts einer finiten Form zum Objekt eines Infinitivs. 8. Typ työ pitää tehdä (kürzere Form des Inf́. I) 'die Arbeit muss getan werden'. Dieser Typ wird zusammen mit den unpersönlichen Verben pitä̈̈̈ 'sollen', täytyä 'müssen', tulla 'sollen', tarvita 'brauchen', sopia 'sich eignen', kelvata 'taugen' usw. gebraucht. -- Das Nomen (tÿ̈), heute als Objekt des Infinitivs aufgefasst, war ursprïnglich Subjekt der finiten Form, die also persönlich gebraucht wurde. Der Satz isännän pitää tappaa koira 'der Hausherr soll den Hund töten' wurde demnach ungefähr folgendermassen aufgefasst: 'der Hund soll dem Hausherrn ein zu tötender sein'. -

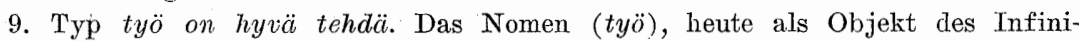
tivs aufgefasst ('es ist' gut, die Arbeit auszuführen'), war ursprünglich Subjekt des Satzes ('die Arbeit lässt sich gut ausführen'). Der Infinitiv stellte eine Bestimmung des Adjektivs dar. - 10. Typ työ jä̈̈̈ tekemättä (Inf. III Abess.) 'die Arbeit bleibt unverrichtet'. Das Nomen (työ) wird noch in der heutigen Sprache. häufig als Subjekt des Satzes aufgefasst; infolge einer Verschiebung der Gliederung gibt es auch folgenden 'Typ: jäi tekemättä työtä 'es wurde nicht gearbeitet', minulta jäi käymättä Helsingissä 'es wurde nichts aus meinem Besuch in Helsinki'.

IV. Verschiebung des Objekts einer finiten Form zum Objekt eines passiven Partizips. 11. Typ saan työn tendyksi (mundartlich tehtyä, vgl. Punkt 5) 'ich bringe es fertig, die Arbeit auszufülhren'. Das Nomen (työn), ursprünglich Objekt der finiten Form, muss in der Sprache der Gegenwart oftmals als Objekt des Partizips aufgefasst werden, z.B. sain sanotuksi tärkeimmät seikat 'ich konnte die wiehtigsten Dinge sagen'. Auch Partizipien von intransitiven Verben kommen zur Verwendung: cn sacnut nukutukssi 'ich konnte nicht schlafen'. - 12. Typ määrä̈̈n työn tehtävälksi 'ich ordne die Ausführung der Arbeit an' (vgl. Punkt 6). In der heutigen Sprache muss das Nomen (työn) oft als Objekt des Partizips aufgefasst werden, z.B. Pakistan on ehdottanut $Y K: n$ joukkoja lähetettäväksi Kashmiriin 'Pakistan hat vorgeschlagen, dass 'Truppen der UN nach Kaschmir gesandt werden sollen'. Näheres s. TKoLA UAJb XXVIII S. 201 f. - 13. Typ näen työn tehtävän (tehtäväksi) bzw. tehdyn (tehdyksi) (Partiz. I bzw. It Pass. Akk. bzw. Transl. Sg.) 'ich sehe, dass die Arbeit ausgeführt wird bzw. worden ist. Das Nomen (työn) war ursprünglich Objekt der finiten Form, ist aber Objekt des Partizips geworden.

V. Verschiebung des Objekts einer finiten Form zum Objekt eines Infinitivs. 14. Typ saan, tahdon, koetan usw. työn tehdä (kürzere Form des Inf. 1; selten die längere Form tehdäkseni) 'ich darf, will; versuche usw. die Arbeit aus(zu)führen'. Die Subjektperson des Infinitivs ist dieselbe wie die des regierenden Verbs. Ausgangspunkt war teilweise der Typ, bei 
dem das Nomen ( tehd̈̈ ist also verstanden worden: 'ich bekomme die Arbeit, um sie auszuführen'. Heute ist das Nomen im allgemeinen als Objekt des Infinitivs aufzufassen, es kann aber auch fehlen. - 15. Typ annan, sallin, käsken työn tehd̈a 'ich lasse, erlaube, befehle die Arbeit aus(zu)führen'. Dieser Typ unterlag derselben Entwicklung wie der vorher aufgeführte. Die hier der Pexson des regierenden Verbs nicht entsprechende Subjektperson des Inf. kann mit einem Dativgenitiv ausgedrückt werden. Annan pojan tehdä työn 'ich lasse den Jungen die Arbeit ausführen' wurde z.B. ursprünglich aufgefasst: 'ich gebe dem Jungen die Arbeit, damit er sie ausführe' - 16. Typ otan työn tehdäkseni (längere Form des Inf. I) 'ich übernehme die Ausführung der Arbeit'. Das Nomen (työn), ursprünglich Objekt der finiten Form, ist heute in den meisten Fällen als Objekt des Infinitivs aufzufassen, z.B. hän on ottanut iehdäkseen työtä 'er hat sich zum Arbeiten entschlossen', ovi ei ota avautuakseen 'die Tür will sich nicht öffnen lassen'. - 17. Typ jätän työn tekemättä 'ich lasse die Arbeit unverrichtet' (vgl. Punkt 10). In einigen Fällen ist das Nomen (työn) heute als Objekt des Infinitivs aufzufassen oder es fehlt, z.B. olen jättänyt kertomatta eräistä hankauksista 'ich habe es unterlassen, von einigen Reibungen zu berichten'.

Die Anzahl der oben angeführten Fälle zeigt, dass es sich hier um eine recht umfangreiche syntaktische Verschiebungstendenz handelt. Infolge derartiger. Verschiebungen haben die Infinitive und die passiven Partizipien als Bestimmung ein Objekt erhalten, was ursprünglich ja nicht möglich war. 